\title{
Analysis of the Influence of Service Quality and Hospital Image on Inpatient Loyalty with Patient Satisfaction as Intervening Variable
}

\author{
Sukartini', Ratna Indrawati $\mathbf{L}^{2}$ \\ University of Esa Unggul Jakarta ${ }^{1,2}$
}

\begin{abstract}
Service quality affects patient satisfaction that will affect patient loyalty. The most important indicators of Hospital services by Ministry of health is the ratio of Bed Occupancy (BOR). If the patient is satisfied with health services provided, then it will effect conferring on patient loyalty to utilize health services. The image of the hospital have an impact on the attitudes and behaviour of patients against hospitals. The better image will be higher levels of consumer purchases and the greater chance of that product being purchased by consumers and further improve consumer loyalty to a product.
\end{abstract}

Purpose: to know the influence of service quality and hospital image on inpatient loyalty with patient satisfaction as an intervening variable.

Research methods: This research is quantitative research. This study was conducted on 185 patients at Mother and Child Hospital "Bunda Sejahtera" Tangerang using a questionnaire. Data analysis method in this research used Structural Equation Modeling (SEM).

Research results: showed that a good hospital image did not improve patient satisfaction. Good service quality will increase patient satisfaction. High patient satisfaction will increase loyalty. A good hospital image will increase patient loyalty. Good service quality will increase patient loyalty. In this study patient satisfaction mediates the Service Quality and Hospital Image because the results of the study show that satisfaction influences patient loyalty.

Key words: Service Quality, Hospital Image, Satisfaction, Loyalty.

\section{INTRODUCTION}

Hospital as a health service industry basically aims to provide satisfaction for its patients. Service quality is very important in improving patient satisfaction and by itself will foster the image of the Hospital. So the Hospital must provide quality services to increase visits and give the impression of quality and competency in handling each patient. Loyal customers mean previous customers with companies and buy more of our products. Customer satisfaction will generate loyalty, the relationship between satisfaction and loyalty is a commitment held in depth to buy or support the product or service that they like in the future even though the influence of the situation and marketing efforts has the potential to cause customers to switch (Kotler and Keller, 2013).

One of the most important indicators of Hospital services by the Ministry of Health is the Bed Occupancy Ratio (BOR), the percentage of Hospital bed usage in a certain period of time. This ratio is useful for determining the level of utilization, quality, and efficiency of hospital services. The Ministry of Health expects Hospitals to have a BOR between 60 percent - 85 percent. Indonesia has a lower BOR overall when compared with neighboring countries with relatively higher BOR such as Singapore (around 90 percent) and Vietnam (around 170 percent), the presence of medical tourism attraction from private hospitals with comprehensive services for foreign patients in these countries.

Image is basically one of the hopes to be achieved and can help in growth and development. Without the help of image, consumers have difficulty in making decisions to buy purchased products (Arindita and Sulistyaningtyas, 2011). At present, with more open public insight into the quality of a product, image becomes very important. A positive image and believed by consumers can meet their needs and desires, then by itself will grow consumer purchasing decisions on the goods and services offered. The better the image of the company, the higher the level of consumer purchase and the greater the chance that the product will be bought back by consumers and further increases consumer loyalty to a product (Laksono, 2008). Positive image is the source of Hospital success to increase patient satisfaction and maintain customer loyalty. 


\section{International Advanced Research Journal in Science, Engineering and Technology}

Vol. 5, Issue 9, September 2018

An image appears based on the knowledge and information a person receives on an object. If the information is good it will cause a positive image, but on the contrary if the information received is bad, it will cause a negative image. In accordance with $\mathrm{Wu}$ (2011) which showed that there is a positive relationship between the image of the Hospital with patient loyalty through improved service and patient satisfaction.

Previous research on service quality, satisfaction and loyalty has been carried out by Sphetim (2012) but as far as there has been no research that makes hospital type $\mathrm{C}$ as the object of research and satisfaction as the mediating variable in the hospital industry. In this study it aims to examine the Influence of Service Quality and Hospital Image on Inpatient Loyalty Hospitalization and patient satisfaction as Intervening variable not found in previous studies.

\section{LITERATURE REVIEW}

Loyalty: Griffin (2010) loyalty is defined as non random purchase expressed over time by some decisions making unit. From this sentence, it appears that loyalty is more aimed at a behavior that is aimed at routine purchases, based on the decision-making unit. Loyalty is measuring the customer's commitment to continue to stay with the provider (Lin and Ding, 2006), then some indicators in the variable of customer loyalty are: Repeat patronage, switching behaviour, dan refferal. The indicator: Repeat Patronage: I will continue to repeat patronage. Sure of the overall quality will not decrease. Sure of the quality will increase in the future. Switching Behavior: Will not move to another hospital. Will not move, even though there are other hospitals that are closer. Will not move, even though there are other hospitals that are cheaper. Referrals: Will tell you more. I'm happy if my friends. Keep repeat patronage.

Satisfaction: Schiffman (2011) stated that satisfaction is a person's feeling of pleasure or disappointment resulting from comparing perceived product performance with expectations. Kotler (2012) satisfaction is a feeling of being disappointed or someone who appears after comparing the performance (results) of the product thought about the expected performance or results. If performance is below expectations, customers are not satisfied. If performance meets expectations, customers are satisfied. If performance exceeds expectations, then the customer is very satisfied or very happy. By understanding the level of satisfaction with the services provided, the company can find out the gap between what the company does and what customers need, thus the company can determine the right steps to make improvements in the future.

Image: Kotler (2013) stated image is a person's beliefs, ideas and impressions of something. For a company, a good image is absolutely necessary. So important as to the meaning of the image itself that the company is willing to spend extra costs and energy to achieve it. Roberts and Dowling (2002) stated that image is an intangible asset that is valuable, difficult to imitate, and helps achieve sustained superior performance.

Service Quality: According to Lovelock (2011) quality is: Quality is degree of excellent intended,and the control of variabiity in achieving that excellent, in meeteng the customers requirements. It is said that quality is the level of quality that is expected, and control of diversity in achieving these qualities to meet consumer needs. Kotler( 2013) Quality is our best assurance of custemer allegiance, our strongest defense against foreign competition, and the only path to sustained growth and earning, quality is our best guarantee for customer loyalty, our strongest defense against foreign competition, and the only way to lasting growth and income.

Relationships between variables and Hypothesis Development: The ability to provide quality services that can meet patient expectations is a very important strategy to achieve competitive advantage. Zeithaml et al, (1996) stated that improving service quality can improve favorable behavioral intentions and reduce unfavorable behavioral intentions. Companies must test the impact of their service quality on customer responses, including cues to repurchase or communicate word of mouth. In accordance with the purpose of the study, the number of variables identified, a concept model of the relationship between service quality and patient satisfaction and loyalty can be built. Service quality is formed by five dimensions, namely reliability, responsiveness, assurance, empathy and physical evidence. Patient perceptions of these five dimensions will influence the level of satisfaction and loyalty of patients can even recommend to family, friends and close relatives. To be able to develop well surely there are factors - factors that influenced that is like the image of the brand and the quality of service. The image is the way society perceives (think of) of the company or its products (Kotler, 2010). If the company's image get a good positioning in the minds of customers so customers willing to pay for expensive against products offered by companies and consumers will wear the brand loyal. Kotler and Keller (2010) the quality or quality is overall features and nature of the products or services that impact on its ability to satisfy the needs expressed or implied. The quality of service given the company greatly affect the brand image of the company. Kotler (2010) stated that customer satisfaction is a feeling happy or upset someone who comes after comparing performance results or products that are primed against the expected results or performance. Dwi (2010) States that service quality affects loyalty either directly or indirectly affect loyalty through customer satisfaction. Herizon and Maylina (2003), explained that customer loyalty is formed by images attached to the product/brand of the 


\section{International Advanced Research Journal in Science, Engineering and Technology}

Vol. 5, Issue 9, September 2018

company. It also caused by customer satisfaction obtained for consumption and related company (Anung, 2012). Based on the the research hypothesis is formulated as follows:

Kotler (2013) explained that building an image is important for the survival of the organization in the future. Chinomona (2013) showed that brand experience has a positive influence on brand satisfaction. Wu (2015) who said that brand image has a positive impact on patient satisfaction, which means that the better the brand image obtained by the patient then the patient feels satisfied and attached to the patient's memory of the brand image, the patient's satisfaction will be higher or vice versa . Based on the description above it can be arranged as follows:H1: Hospital image has a positive influence on customer satisfaction.

Product quality both goods and services are important and expected by consumers. Other studies such as those conducted by $\mathrm{Wu}$ (2011) state that high service quality correlates with high customer satisfaction. Patient satisfaction functions as a medium between service quality and behavioral intention. Ariyani and Rosinta (2010) showed that there is a strong and positive influence between the variable of quality of KFC services on customer satisfaction in FISIP UI students. Shpetim (2012) showed that service quality has a positive relationship to satisfaction. from the description above, the writer compiled:

H2: Service quality has a positive influence on customer satisfaction.

Customer satisfaction is a function of performance that is considered to exist in the product or service and expectations of the buyer (Kotler, 2010). Mohzan et al. (2011) examined the impact of customer satisfaction on customer loyalty and the impact of customer satisfaction on transfer intention. Shpetim's (2012) research showed satisfaction has a positive relationship to loyalty and trust has a positive relationship to loyalty. From the description above, the writer compiled: H3: Customer satisfaction has a positive influence on loyalty

Keller (2003) argued that the relationship between brand image and loyalty is that basically a positive brand image can increase the likelihood of choice for the brand. Normasari et al. (2013), showed that corporate image variables have a significant influence on customer loyalty variables. However, the image can be seen clearly as a estimator of customer loyalty. A good image will shape the mindset of the community that if people have health problems, people do not need to think twice about where they will get health services, because based on experience they experience themselves or based on the information they obtain. From the description above, the writer compiled:H4: Hospital image has a positive influence on loyalty

Whether consumers are Loyal or not consumers can be seen from the satisfaction they feel. Consumers are satisfied that their expectations are met and feel very happy if their expectations are exceeded. if the customer feels satisfied in making a purchase, then he will pay more attention to the buyer opportunity in the next opportunity. Wungow (2013) shows that service quality, image, value and satisfaction variables simultaneously have a significant effect on loyalty. Darlina (2015) proved that the provision of service quality has a significant influence on customer loyalty, and a significant influence between corporate image and service quality on customer loyalty. From the description above, the writer compiled:H5: Service quality has a positive influence on loyalty.

Research Method: Based on the hypothesis in the design of this study determined the variables used in the study. There are four variables: service quality, brand image, patient satisfaction and patient loyalty. Data collection was done by distributing questionnaires. The collected data was processed using descriptive and quantitative analysis tools. The analysis technique used to analyze the data was SEM (Structural Equation Model) analysis. Program Lisrel. The sample chosen was inpatients at the Mother and Child Bunda Sejahtera Hospital.

The requirements for determining the number of samples were determined by Hair, et al. (1998) which stated that the number of samples taken is at least five times the number of parameters used in the study. The research questionnaire contained 37 statements, having 4 observed variables. This the number of samples needed was 5 x $37=185$ respondents. The data that has been collected was then carried out a Likert measurement scale with a scale of one to five.

\section{Structural Equation Model (SEM).}

Table 5.1: Analysis of the Goodness of Fit

\begin{tabular}{|l|l|l|l|}
\hline Group & Indicator & Value & Keterangan \\
\hline \multirow{4}{*}{1} & Degree of Freedom & 159 & \\
\cline { 2 - 3 } & Chi Square & 283,31 & \multirow{4}{*}{ Good fit } \\
\cline { 2 - 3 } & NCP & 105,82 & \\
\cline { 2 - 3 } & Confidence Interval & $(64,94 ; 154,59)$ & \\
\hline \multirow{4}{*}{2} & RMSEA & 0,060 & \\
\cline { 2 - 3 } & Confidence Interval & $(1,77 ; 2,26)$ & \\
\cline { 2 - 3 } & P Value & 0,097 & Good fit \\
\hline 3 & ECVI Model & 1,99 & \\
\hline
\end{tabular}




\section{International Advanced Research Journal in Science, Engineering and Technology}

Vol. 5, Issue 9, September 2018

\begin{tabular}{|c|c|c|c|}
\hline Group & Indicator & Value & Keterangan \\
\hline & ECVI Saturated & 2,28 & \\
\hline & ECVI Independence & 19,97 & \\
\hline & Confidence Interval & 0,$55 ; 0,68$ & \\
\hline \multirow[t]{6}{*}{4} & AIC Model & 366,82 & \multirow{6}{*}{ Good fit } \\
\hline & AIC Saturated & 420,00 & \\
\hline & AIC Independence & 3675,31 & \\
\hline & CAIC Model & 582,06 & \\
\hline & CAIC Saturated & 1306,27 & \\
\hline & CAIC Independence & 3759,72 & \\
\hline \multirow[t]{6}{*}{5} & NFI & 0,92 & \multirow{6}{*}{ Good fit } \\
\hline & CFI & 0,96 & \\
\hline & NNFI & 0,96 & \\
\hline & IFI & 0,96 & \\
\hline & RFI & 0,91 & \\
\hline & PNFI & 0,77 & \\
\hline 6 & Critical N & 133,10 & Marginal fit \\
\hline \multirow[t]{4}{*}{7} & Standardized RMR & 0,085 & \multirow{4}{*}{ Marginal fit } \\
\hline & GFI & 0,87 & \\
\hline & AGFI & 0,83 & \\
\hline & PGFI & 0,66 & \\
\hline
\end{tabular}

Source: SEM test results

\section{RESULT AND DISCUSSION}

The instrument used in this study has been tested in validity and reliability thus the results of Construct Reliability and Variance Extracted KP value of VE 0.41, CR value is VE, 0.35, VE value is 0, 66, LP value is VE 0.60, goodness of fit, where Chi Square $=283.31$ Degree of Freedom $=159$, ECVI $=1.99$, AIC $=366.82$, CAIC $=582.06$, Critical $\mathrm{N}=$ 133.10 $\mathrm{RMR}=0.085$ and $\mathrm{PGFI}=0.66$. Furthermore, this research produced value diagrams as in the following figure:

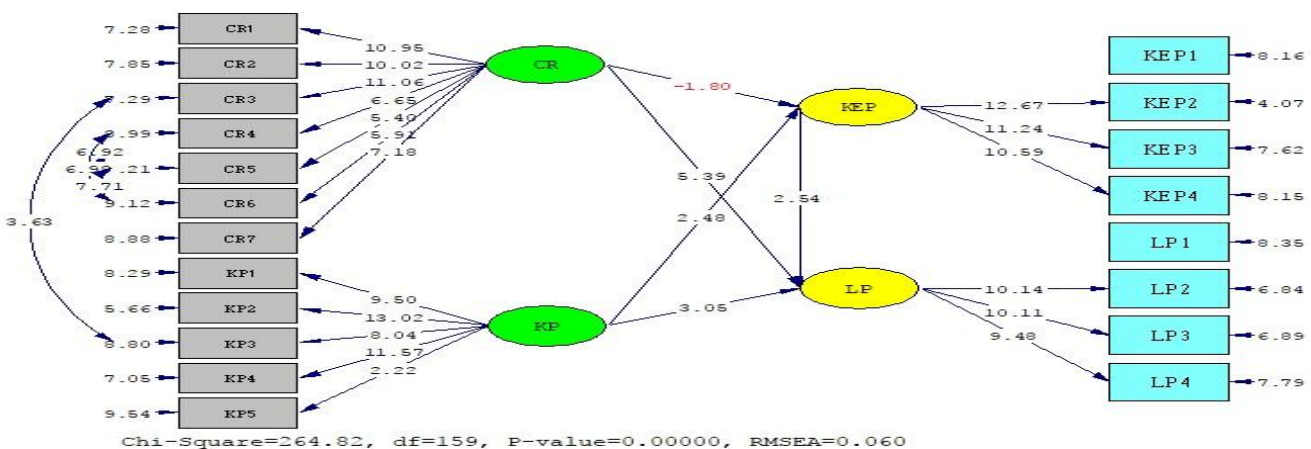

Figure 5.1: Path Diagram T-Value

Table 5.2: Research Model Hypothesis Testing

\begin{tabular}{|l|l|l|l|}
\hline Hypothesis & Statement of Hypothesis & Value of T-Value & Note \\
\hline $\mathrm{H}_{1}$ & $\begin{array}{l}\text { A good hospital image increases } \\
\text { patient satisfaction }\end{array}$ & $-1,80$ & $\begin{array}{l}\text { The data does not } \\
\text { support the hypothesis }\end{array}$ \\
\hline $\mathrm{H}_{2}$ & $\begin{array}{l}\text { High quality service improves } \\
\text { patient satisfaction. }\end{array}$ & 2,48 & $\begin{array}{l}\text { The data supports the } \\
\text { hypothesis }\end{array}$ \\
\hline $\mathrm{H}_{3}$ & $\begin{array}{l}\text { High satisfaction increases } \\
\text { loyalty }\end{array}$ & 2,54 & $\begin{array}{l}\text { The data supports the } \\
\text { hypothesis }\end{array}$ \\
\hline $\mathrm{H}_{4}$ & $\begin{array}{l}\text { A good hospital image increases } \\
\text { patient loyalty. }\end{array}$ & 5,39 & $\begin{array}{l}\text { The data supports the } \\
\text { hypothesis }\end{array}$ \\
\hline $\mathrm{H}_{5}$ & $\begin{array}{l}\text { High quality service increases } \\
\text { patient loyalty. }\end{array}$ & 3,05 & $\begin{array}{l}\text { The data supports the } \\
\text { hypothesis }\end{array}$ \\
\hline
\end{tabular}

Source: Test results on data analysis tools 


\section{International Advanced Research Journal in Science, Engineering and Technology}

Vol. 5, Issue 9, September 2018

\section{Hospital Image Has No Positive Influence Increasing Satisfaction}

In the results of the first hypothesis (H1) testing it was found that the results of the analysis did not support hypothesis H1 that good Hospital Image does not increase patient satisfaction. This shows that the Hospital Image has no influence on patient / customer satisfaction and patient satisfaction is not only influenced by the image of Hospital . A good hospital image cannot reduce patient or customer satisfaction, and vice versa, a bad / bad hospital image cannot increase or decrease patient or customer satisfaction. This is because an image is formed by communication, word of mouth and experience, while satisfaction is a comparison between the expectations and realities received by consumers, even though the hospital's image is positive but if the patient has never felt the service then the patient cannot feel his satisfaction. Thus the image is expected to have a positive impact on customer satisfaction. Because the patient's health is a referral patient from a midwife, so that my patient does not understand the condition about the hospital, and the patient's expectations are not in accordance with what is expected thus the patient does not feel satisfied. Kotler (2010) explained that building an image is important for the survival of the organization in the future.

Customer satisfaction is a level where consumers feel happy or disappointed with a product. Consumers will say they are satisfied with an item if they have a good perception of a product. Kotler and Armstrong (2001) argued that consumers are satisfied with the product purchased in accordance with what is desired and the expectations of consumers. If the brand has given satisfaction, then consumers usually do positive words of mouth to people related to the brand in the product they have bought. Many companies deliberately give satisfaction to the brand, in order to increase profits for the company. Therefore, brand formation in products is very necessary, because it is a decision of attitude or behavior on the consumer. So a positive brand image will cause satisfaction to its customers.

This study is in accordance with Lahap's research (2015) revealed that brand image does not influence customer satisfaction in the context of the Malaysian hotel industry. Thus, this research is valuable because it strengthens further understanding of what customers really want when choosing a hotel. Therefore, this research has the capacity to offer hotel operators a way to plan, formulate, and decide to what extent they must improve their brand image to compete in the long term. Wenur (2015) stated that brand image partially has no significant influence on consumer satisfaction. This means that a well-known brand does not guarantee consumers are satisfied because consumers also see the quality factor of the product. In products consumers see that the image of the research is closely related to the green marketing strategy carried out thus the image and strategy cannot be separated, or can be related to other factors such as quality products.

This is not in accordance with the research presented by Da Silva et al. (2003) stated that image correlated with customer satisfaction. Based on the experience that has been owned by consumers (patients), they will provide an assessment and evaluation of all hospital service performance. Based on the comparison of the quality of expectations with the quality of service performance, the customer will give positive emotions or negative emotions even neutral emotions, depending on whether the customer's expectations were met.

Another consideration from the results of the hypothesis of the researcher who stated that the image had no effect on satisfaction was the place in which the research was carried out namely the private hospital and significant research were carried out in company and store companies. The researcher also saw that there are influences from other conditions which make this study insignificant, namely the time when the research on conditions of hospitals experiencing an uncertain era of the implementation of the National health insurance system also contributed significantly. Patients will be satisfied with the services / products they buy according to their expectations and desires, if the brand has given satisfaction, then patients usually do positive words of mouth to people related to the brands in the products they have bought. the image must be built through all existing and sustainable media and the message can be conveyed through symbols, media or visual, atmosphere, and events.

Currently we often hear the image of public sector institutions that are often considered lacking, people have a poor perception of the services provided. One of them is in the field of health services. People still argue that health services in private hospitals are more expensive than government hospitals. Often this is what makes people prefer to seek treatment at government hospitals and create a negative stigma on private hospitals. This poor private hospital image can influence patient satisfaction. A good institutional image will give rise to certain perceptions of service users. We can understand this because the positive image of a hospital comes from good service to patients carried out consistently over a long period of time. Thus prospective patients and their families will feel a positive perception of the hospital.

\section{High Service Quality Increases Satisfaction}

In the results of the second hypothesis $(\mathrm{H} 2)$ testing, it was found that the results of the analysis supported hypothesis $\mathrm{H} 2$ that high service quality increases patient satisfaction. From the results of this test showed that the quality of service influences satisfaction. Seen in Path Diagram T.Value (Figure 5.2) that the quality of service in this study used 5 dimensions which include: Tangible (KP1) of 9.50, Reliability (KP2) of 13.02, Responsiveness (KP3) of 8.04, Assurance (KP4) of 11.57 and Emphaty (KP5) of 2.22.

It can be seen from the values of these dimensions that the quality of Reliability services with the highest value on patient satisfaction. This means that the company is able to provide services as promised in an accurate and reliable 


\section{International Advanced Research Journal in Science, Engineering and Technology}

Vol. 5, Issue 9, September 2018

manner. Performance must be in accordance with customer expectations which means timeliness, equal service for all customers without mistakes, sympathetic attitude and with high accuracy. This will create a good impression and judgment in the eyes of the patient on the quality of the hospital's services. Therefore the quality of service must start from the customer's needs and end in the customer's perception (Kotler, 2010). Furthermore Lewis and Booms (2007) suggested that service quality is a measure of how well the level of service provided is in accordance with customer expectations, service quality can be realized through customer fulfillment and desires and delivery accuracy to offset customer expectations.

The company's ability to deliver promised services accurately from the first time, for example a company might choose a consultant based solely on reputation. If the consultant is able to provide what the client wants, the client will be satisfied and pay a consultation fee. However, if the consultant realizes what is expected by the client, the consultation fee will not be paid in full (Tjiptono, 2012). Each service requires a reliable form of service, meaning that in providing services, every employee is expected to have the ability in knowledge, expertise, independence, mastery and high professionalism of work, thus work activities undertaken produce a satisfying form of service, without complaints and excessive impressions for services received by the community (Parasuraman, 2001). The demand for employee reliability in providing fast, precise, easy and smooth services is an assessment requirement for the person served in showing the actualization of employee work in understanding the scope and work description that becomes the attention and focus of each employee in providing services. The core of service reliability is that every employee has reliable abilities, knows about work procedures, work mechanisms, corrects various deficiencies or irregularities that are not in accordance with work procedures and able to show, direct and provide correct direction to any form of service that is not understood by the public, thus giving a positive impact on the service, namely employees understand, master, reliable, independent and professional for the work descriptions they pursue (Parasuraman, 2001). The relationship of dimension of service reliability (reliability) is very important in the dynamics of the work of an organization. Reliability is a characteristic or characteristic of employees who have high job performance. Reliability in service delivery can be seen from the reliability of providing services in accordance with the level of knowledge based on the level of knowledge possessed, reliability in skilled mastering the applied field of work, reliability in mastering the field of work according to demonstrated work experience and reliability using work technology.

The results of this study are in line with the Research of Ariyani and Rosinta (2010), showing that there is a strong and positive influence between the variable quality of KFC services on customer satisfaction in FISIP UI students. Shpetim (2012) showed that service quality has a positive relationship to satisfaction. And also the study of Normasari et al. (2013) aimed to know the influence of service quality on customer satisfaction. Alrubaiee (2011) who said that the quality of health services has a positive impact on patient satisfaction.

\section{High Satisfaction Increases Loyalty}

In the results of the third hypothesis (H3) testing, it was found that the results of the analysis supported hypothesis H3 that high satisfaction increases patient loyalty. This shows that the Hospital Service Quality of RSIA Bunda Sejahtera has been able to provide good service that exceeds the expectations of patients so as to cause good satisfaction. This indicates that patients who are satisfied means feeling at home, comfortable with the Quality of Hospital Services of RSIA Bunda Sejahtera, which in the end patients do not hesitate prioritizing RSIA Hospital Bunda Sejahtera being the main choice for treatment that it raises loyalty. Tjiptono (2012) stated that satisfaction can encourage customer / patient loyalty. Patient satisfaction is one of the important assessments of the features of service, where the quality of service must be able to make patients feel comfortable and satisfied. The level of patient satisfaction influences the quality of service which prioritizes the fulfillment of the needs of the consumers. The feeling of satisfaction that arises is the key to generating patient loyalty by providing high patient value. Besides, the emergence of patient satisfaction depends heavily on patient perceptions and expectations.

The results of this study are in line with previous research conducted by Mohzan et al. (2011), aimed to examine the impact of customer satisfaction on customer loyalty and the impact of customer satisfaction on the intention to switch. Shpetim (2012) showed satisfaction has a positive relationship to loyalty and trust has a positive relationship to loyalty. Normasari et al. (2013), showed that customer satisfaction has a significant influence on the variable of the company's image and on customer loyalty that customer satisfaction has a significant customer loyalty, increasing customer satisfaction will bring customers who are more loyal to the company. Selnes (1993) showed that customer satisfaction influences buyer behavior which satisfied customers tend to be loyal.

\section{Positive hospital image influences loyalty}

In the results of the fourth hypothesis (H4) testing, it was found that the results of the analysis supported hypothesis H4, namely a good Hospital Image increases patient loyalty. From the results of this test, it shows that the hospital image influences patient loyalty. Seen in Path Diagram T.Value (Figure 5.2) that the Hospital Image in this study used 7 indicators which include: CR1 of 0.75, CR2 of 0.70, CR3 of 0.74, CR4 of 0.50, CR5 of 0.41, CR6 of 0.45, and CR7 of 0.53. Image is a set of beliefs and impressions of an object to an object determines one's attitude towards the object. Company image is believed to be an important factor that increases customer loyalty (Kottler, 1997). Wu (2011) 


\section{International Advanced Research Journal in Science, Engineering and Technology}

Vol. 5, Issue 9, September 2018

revealed that Hospital Image directly or indirectly influences customer loyalty. Good names that arise in the minds of patients / customers when they hear the name of the business, which means known to customers / patients as a good service company makes these customers loyal to the company and even recommend to relatives. A good image will shape the mindset of the community that if people have health problems, people do not need to think twice about where they will get health services, because based on experience they have or based on the information they obtain. Normasari et al. (2013), showed that corporate image variable has a significant influence on customer loyalty variable. However, the image can be seen clearly as an estimator of customer loyalty. A good image will shape the mindset of the community that if people have health problems, people do not need to think twice about where they will get health services, because based on experience they experience themselves or based on the information they obtain. Hidajahningtyas (2013), showed that the hospital image variable has a significant relationship to loyalty.

\section{High Service Quality Increases Loyalty}

In the results of the fifth hypothesis (H5) testing, it was found that the results of the analysis supported hypothesis H5, namely high service quality increased patient loyalty. From the results of this test, it shows hat Service Quality influenced patient loyalty. Seen in Path Diagram T.Value (Figure 5.2) that the Quality of Service in this study used 5 dimensions which include: Tangible (KP1) of 9.50, Reliability (KP2) of 13.02, Responsiveness (KP3) of 8.04, Assurance (KP4) of 11.57 and Emphaty (KP5) of 2.22. The dimensions of these dimensions can be seen that the quality of Reliability services with the highest value on patient loyalty. It can be interpreted that service quality is the ability to carry out the promised services reliably and accurately. This means the level of reliability in the eyes of the customer, including the ability to provide the promised service immediately, accurately, and satisfactorily which includes complete transaction records, credibility / bona fide / corporate image and the attractiveness of superior service quality. In this case RSIA Bunda Sejahtera medical officers provide appropriate services accurately and reliably, sympathetic and with high accuracy to the patients. Reliability is measured by accurate service actions by medical personnel, professionalism in handling patient complaints by medical personnel, serve well and kindly when doing treatment and care, providing services correctly in accordance with the procedures set out in providing services always in accordance with a predetermined schedule. Reliability means the ability of the company to provide accurate services from the first time without making any mistakes and deliver its services according to a certain time, the point of which is reliability when all patients believe that health services in certain health places for them are very satisfying and as expected.

Accurate services (reliability) and providing the service that is promised immediately by medical personnel in working with the right results can create a professional impression on medical personnel in Bunda Sejahtera Hospital. The results of the right service or can be said in accordance with what the patient needs, of course, can make the patient feel comfortable and safe in undergoing treatment at RSIA Bunda Sejahtera thus it can make patients be loyal. In addition, the provision of services promised with immediate and accurate service by hospital staff in working can minimize or even cause no complaints from patients.. This can make the patient not hesitate to reuse the services of RSIA Ibu Sejahtera for treatment or can be said to be the attitude of loyalty shown by the patient. Besides this condition can bring the good name of RSIA Bunda Sejahtera in the eyes of the community. The patient's good experience in undergoing treatment at RSIA Bunda Sejahtera, is expected to make the patient tell his good experiences to the people closest to him. This attitude can also be said as one of the loyal attitudes. Guilitnan (1997) suggested that one of the benefits of customer satisfaction is that it can increase customer loyalty.

This can provide a thrust for patients to establish mutually beneficial relationships for the future of RSIA Bunda Sejahtera hospital. Therefore, patients do not hesitate in prioritizing RSIA Bunda Sejahtera as the main hospital choice to be visited again as a form of loyalty from their patients. The results of this study further corroborate the results of Wungow's previous research (2013), showing that service quality, image, value and satisfaction variables simultaneously have a significant influence on loyalty.. Darlina (2015), that the provision of service quality has a significant influence on customer loyalty, and a significant influence between corporate image and service quality on customer loyalty. This means that consumers who are satisfied with buying green cosmetic products will encourage the creation of loyal customers. Osman et al., (2015) showed that service quality has a significant and positive influence on loyalty in Malaysian rural tourism.

\section{Satisfaction Mediation Analysis}

Mediation variable analysis can be done through two approaches, namely: coefficient and multiplication differences. The first approach is done by conducting an examination through analysis with and without mediating variables, while the second method is done using the Sobel procedure (Hair, et al., 2006). Through the coefficient multiplication method, the results of research hypothesis testing showed the influence of mediating variables on patient satisfaction between service quality variables on patient loyalty. The mediating variable of patient satisfaction was used to bridge the relationship between service quality and patient loyalty.

Based on the results of the coefficient difference on the research model, it can be seen that service quality had a direct influence on patient satisfaction with $\mathrm{t}=2.48(>1.96)$, service quality had a direct influence on loyalty with $\mathrm{t}$ value $=3,05$ $(>1,96)$ and service satisfaction influenced loyalty with a value of $t=2.54(>1.96)$. Hospital image had an 


\section{International Advanced Research Journal in Science, Engineering and Technology}

Vol. 5, Issue 9, September 2018

indirect influence on patient satisfaction with $\mathrm{t}=-1.80(<1.96)$, hospital image had a direct influence on loyalty with $\mathrm{t}$ value $=5.39(>1.96)$ thus it can be concluded that patient satisfaction can mediate the relationship between Service Quality and Hospital Image with patient loyalty. Service quality directly influenced patient loyalty and service quality had an indirect influence on patient loyalty through mediating patient satisfaction. This is commonly called partial mediation analysis because it can influence directly and indirectly. Patient satisfaction can mediate partial hospital image relationships.

The results of the analysis showed that patient satisfaction can mediate between service quality and patient loyalty. Where the better the Quality of Service provided, the higher the patient satisfaction. Good service quality is a quality that is able to meet the desires of its customers, thus customers feel satisfied with the results of the quality of service received. In each company, customer satisfaction is very important because if the customer is satisfied with a service or product, then the position of the product or service will get a good assessment in the eyes of its customers. This causes customers to no longer hesitate to consume the product or service on an ongoing basis. This attitude is called customer loyalty. Products or services that satisfy their customers make customers feel happy and have an interest in the product or service, thus customers remain loyal and do not easily switch to buying products or services from other competitors. The results of the study found that the hospital image variable had no influence on patient satisfaction. Service quality has proven to have a significant and positive influence on loyalty through customer satisfaction. The results of this study are consistent with research conducted by Wu (2011) who found that image has an indirect influence on loyalty through customer satisfaction. The results are also not in accordance with the research of Ariyani and Rosinta (2010) who found that service quality had an indirect influence on loyalty through satisfaction. A good image will shape the mindset of the community that if people have health problems, people do not need to think twice about where they will get health services, because based on experience they experience themselves or based on the information they obtain. Likewise, the implementation of service quality carried out by a company is to provide the best service for patients with the aim of creating patient satisfaction and ultimately forming loyalty. The quality of service provided by the company will lead to patient perception. A good perception of the quality of service received and the image of a good hospital, the greater patient expectations are fulfilled then the patient's satisfaction would be greater. High satisfaction in patients will also cause high patient loyalty.

\section{CONCLUSION AND SUGGESTIONS}

\section{Conclusion}

The results of this study are expected to be useful for the policy of Bunda Sejahtera Hospital that supports patient loyalty in Bunda Sejahtera Hospital. Based on these studies, the researcher concluded that: (i) Hospital image does not influence customer / patient satisfaction at RSIA Bunda Sejahtera Tangerang for as much as (ii) Service quality significantly influences customer / patient satisfaction in RSIA Bunda Sejahtera Tangerang. (iii) Customer satisfaction significantly influences customer loyalty in RSIA Bunda Sejahtera Tangerang. (iv) Hospital image significantly influences customer loyalty in RSIA Bunda Sejahtera Tangerang. (v) Quality of service significantly influences customer / patient loyalty in RSIA Bunda Sejahtera.

\section{Research Limitations}

The researcher realized that the results of this study still have limitations including: (i) this study was only carried out on inpatients treated at RSIA Bunda Sejahtera with the criteria of the researcher. (ii) respondents who were sampled in this study were quite heterogeneous in terms of patient status. (iii) the inconsistency of respondents' answers in answering the list of questions (questionnaires) because the health and psychological conditions when the patients in answering questionnaire questions will certainly influence the appraisal of these hospital services, thus the data provided has not been able to explore the actual conditions.

\section{Suggestions}

Based on the above conclusions, suggestions can be proposed as follows: (i) for the Company, Mother and Child Hospital Mother Prosperity is advised to be communicative and always interact with patients, Good quality of service will create loyalty and warmth in the eyes of consumers, whether or not the quality service of a service is very relative in nature. (ii) for the head of the nursing field, there needs to be a service recovery carried out by the public, medical services, SIMRS facilities and installations by improving hospital services as early as possible, based on priorities such as patient waiting room comfort facilities, inpatient service rooms, information and technology and service flow improvement and as well as complementing medical support facilities.(iii) The field of medical services needs to continuously monitor and evaluate the quality of service and the image of the hospital as well as patient loyalty to the hospital through patient satisfaction surveys and quick responses to the suggestion and criticism boxes addressed to patients. Need to increase the reward and punishment system for officers in providing services to motivate officers in providing good services to patients. (iv) for patients, each patient's complaint of service is expected to be delivered to the Hospital and request an explanation regarding the obstacles and complaints of services felt to the Hospital 


\title{
International Advanced Research Journal in Science, Engineering and Technology
}

\author{
Vol. 5, Issue 9, September 2018
}

management directly. (v) for future researchers they should do the same research, with a more homogeneous sample of patients and the need for other studies using qualitative research designs.

\section{REFERENCES}

[1]. Alrubaiee, L. (2011). The Mediating Effect of Patient Satisfaction in the Patients Perceptions of Healthcare Quality - Patient Trust Relationship. International Journal of Marketing Studies Vol. 3 No. 1

[2]. Arindita, Aloysius Reza dan Devi Sulistyaningtyas, Ike. 2013. Pengaruh Kualitas Pelayanan Terhadap Citra Perusahaan di Olimart PT Wina Wira Usaha. Jurnal Ilmu Sosial dan Politik.

[3]. Chinomona Richard. (2013). The Influence of Brand Experience on Brand Satisfaction, Trust, and Attachment In South Africa. International Business and Economics Research Journal. Vol.12, No.10

[4]. Da Silva,R.V. \& Alwi, S.F.S. 2008. Online Corporate Brand Image, Satisfacton, and Loyalty. Journal of Brand Management Vol. 16.

[5]. Darlina D.2015. Pengaruh Citra perusahaan dan kualitas pelayanan terhadap loyalitas pelanggan pada jasa perhotelan. Program Studi Administrasi Bisnis Jurusan Ilmu Administrasi. JOM FISIP Vol 1 No. 3 Februari 2016

[6]. Dwi Aryani Dan Febrina Rosinta. 2010.Pengaruh Kualitas Layanan Terhadap Kepuasan Pelanggan Dalam Membentuk Loyalitas Pelanggan. Bisnis \& Birokrasi, Jurnal Ilmu Administrasi dan Organisasi, Mei- Agus 2010, hlm.114-126,ISSN 0854- 3844

[7]. Faizan Mohsan, Muhammad Musarrat Nawaz, M.Sarfraz Khan, Zeeshan Shaukat, Numan Aslam.2011 Impact of Customer Satisfaction on Customer Loyalty and Intentions to Switch: Evidence from Banking Sector of Pakistan International Journal of Business and Social Sciene, Vol. 2 No. 16, September

[8]. Griffin. (2010),"Customer Loyalty (Menumbuhkan dan Mempertahankan Kesetiaan Pelanggan"). Jakarta : Erlangga.

[9]. Hair, J.F., Babin, B.J., Anderson, R.E and Tatharn, R.L. 2010. Multivariate Data Analysis 6 th ed. Upper Saddle River. New Jersey: Prentice Hall, Inc.

[10]. Johanudin Lahap, Nur Safiah Ramlib , Noraslinda Mohd Saidc, Salleh Mohd Radzid , Razlan Adli Zaine. 2015. A Study of Brand Image towards Customer's Satisfaction in the Malaysian Hotel Industry. 6th International Research Symposium in Service Management, IRSSM-6 2015, 11-15 August 2015, UiTM Sarawak, Kuching, Malaysia.

[11]. Kotler, Philip dan Keller, Kevin Lane. (2009), Manajemen Pemasaran, Edisi 12, Jakarta: PT. Indeks Kelompok Gramedia

[12]. Laksana F, 2008. Manajemen Pemasaran. Yogyakarta: Penerbit Graha Ilmu

[13]. Lin, C.P., and Ding, C.G. (2006), Evaluating the Group Differences In Gender During the Formation of Kualitas relasional and Loyalty in ISP Service, Journal of Organizational and End User Computing, 18, 38-62.

[14]. Lodhi, Nawaz, Rab. 2013. Effect OF Brand Image On Brand Loyalty And Role Of Customer Satisfaction In It. Dalam World Applied Sciences Journal 26 (10): 1364-1370, 2013. Pakistan. Comsats Institute Of Information Technology Sahiwal.

[15]. Lovelock, Wirtz dan Mussry. (2011). Pemasaran Jasa: Manusia, Teknologi, Strategi. Jakarta: Erlangga.

[16]. Normasari, Selvy dkk. 2013. "Pengaruh Kualitas Pelayanan Terhadap Kepuasan Pelanggan, Citra Perusahaan dan Loyalitas Pelanggan Survei pada Tamu Pelanggan yang Menginap di Hotel Pelangi Malang”. Jurnal Administrasi Bisnis. Vol. 6 No. 2 Desember 2013.

[17]. Parasuraman, A, Valerie A. Zeithaml, Leonard L. Berry. 1998 SERVQUAL : A Multiple Item Scale For Measuring Consumer Perception Of Service Quality. Journal Of Retailing Vol. 64 No. 1, pp 12-37.

[18]. Roberts, P. W., \& Dowling, G. R. (2002). Corporate Reputation and Sustained Superior Financial Performance. Strategic Management Journal, 23(12), 1077-1093.

[19]. Schiffman, Leon G., dan Leslie Lazar Kanuk. (2011). Perilaku Konsumen. PT Indeks Group Gramedia, Jakarta

[20]. Supriyanto.S dan Ernawati, 2010. Pemasaran Industri Jasa Kesehatan. Penerbit CV Andi Offset : Yogyakarta.

[21]. Selnes. Fred.(1993). An Examination of the Effect of Product Performance on Brand Reputation, Satisfaction and Loyalty. European Journal of Marketing, Vol. 27 Iss: 9, pp.19-35

[22]. Shpetim Cerri. 2012. Exploring the Relationships among Service Quality, Satisfaction, Trust and Store Loyalty among Retail Customers. Journal of Competitiveness Vol. 4, Issue 4, pp. 16-35, December 2012 ISSN 1804-171X (Print), ISSN 1804-1728 (On-line), DOI: 10.7441/joc.2012.04.02

[23]. Tjiptono,Fandy,gregorius Chandra, 2012. Pemasaran strategik. Yogyakarta: ANDI.

[24]. Wu. C. C., (2011). The Impact of hospital brand image on service quality, patient Satisfaction and loyalty. Journal Feng Chia University, Taiwan

[25]. Wenur Christy.2015. pengaruh strategi green marketing,citra merek,dan kualitas produk terhadap kepuasan konsumen pengguna the body shop,manado town square. Jurnal EMBA 283 Vol.3 No.2 Juni 2015, Hal. 283-293

[26]. Zeithaml, V., Berry, L. dan Parasuraman, A. 1988. "SERQUAL: A Multiple-Item Scale for Measuring Service Quality". Journal of Retailing. Vol.64, No.1, Spring 1988, pp 12-40.

[27]. Zahir Osman et al., (2015). An Empirical Study of Direct Relationship of Service Quality, Customer Satisfaction and Bank Image on Customer Loyalty in Malaysian Commercial Banking Industry. American Journal of Economics, 5(2): 168-176. 